\title{
The Lincoln Highway in Greene County: Highway Politics, Local Initiative, and the Emerging Federal Highway System
}

\section{REBECCA CONARD}

THE LINCOLN HIGHWAY, as America's first cross-continental thoroughfare, played an important role in the evolving federal highway system during the 1920s. Like the transcontinental highways themselves, however, the federal highway system did not spring from engineers' drawing boards. The Lincoln Highway itself began in 1913 "not as a line bridging the continent in a great leap" but as an assortment of existing turnpikes, wagon roads, and established trails between New York City and San Francisco. ${ }^{1}$ By the time it was numbered and merged into the new federal highway system in the late 1920s, it had matured into a (mostly) paved, well-marked, and highly promoted highway.

In the interim, politicians, pressure groups, and federal and state highway officials struggled to fashion a federal highway policy. The larger story turns inevitably on key personalities, major proposals, and the automobile as an

The Lincoln Highway in Greene County was listed on the National Register of Historic Places on March 29, 1993. This article is based on the National Register nomination. I would like to thank Bob and Joyce Ausberger of Jefferson for generously assisting with the research. More important, I would like to thank them for their cheerful tenacity and commitment to preserving the historical remains of this important national highway.

1. Drake Hokanson, The Lincoln Highway: Main Street across America (Iowa City, 1988), 52.

THE ANNALS OF IOWA 52 (Fall 1993). (C)The State Historical Society of Iowa, 1993. 
agent of change. ${ }^{2}$ Yet within this larger story are a myriad of local dramas. When one looks carefully at the local level, or at least certain locales, what is striking is the degree to which ordinary citizens promoted and actively participated in transforming the Lincoln Highway from an "end-to-end collection" of existing pathways into a hard-surfaced, welltraveled ribbon across America. ${ }^{3}$

Historians attracted to the automobile age have explored in some depth the emergence of highway policy, the role of technology, consumer demand, and automotive industry boosterism. By looking at a slice of the Lincoln Highway, though, we can see another force at work: an enterprising spirit perking to the surface, now and again propelling events, gradually shaping popular opinion, and slowly changing voter attitudes. The locus of this particular story is Greene County, whose county seat, Jefferson, sits approximately thirty-five miles west of Ames. There we can see in microcosm the evolving relationship between local initiative and state and federal highway policies.

FROM THE CREATION of the federal government until the good roads movement emerged in the late 1880 s, road building and maintenance were considered functions of local government almost exclusively. Even amid increasing pressures to spread responsibility for road building and maintenance more broadly, the shift was slow to materialize. In $1892 \mathrm{New}$ Jersey became the first state to adopt a plan for providing state aid for road building, and Massachusetts created the first state highway department shortly thereafter. By the end

2. John Rae, The Road and Car in American Life (Cambridge, MA, 1971), $44-49,101-8,208-9$, argues that federal highway policy evolved in response to automobile technology and consumer demand. David J. St. Clair, The Motorization of American Cities (New York, 1986), on the other hand, suggests that while consumers may have played an important role, at least initially, the automobile industry more effectively influenced the direction of federal policy beginning with World War I but especially from the 1930s on.

3. Hokanson, Lincoln Highway, 52. 
of the 1890s, only seven states had established highway departments. ${ }^{4}$

After decades of decentralized control over roads, it was not easy to abandon the tradition. Federal aid for highway construction was practically unheard of except for a few isolated instances, most notably in the act of 1802 that authorized public funds to construct the National Road connecting the eastern tidewater region with frontier settlements along the Ohio River. From time to time, Congress funded military roads in the territories, which was considered a legitimate exercise of federal power. In 1838, for instance, Congress authorized a territorial road in Iowa for military purposes and, a year later, appropriated twenty thousand dollars to build the road, which ran from Dubuque through Iowa City, Mt. Pleasant, and Keosauqua. States admitted between 1803 and 1910 also received small allocations from federal land sales, which were to be used for public roads, canals, and internal improvements. Iowa, however, chose to use its allocation for schools, not roads. ${ }^{5}$ After Rural Free Delivery mail service was introduced in 1896, the Office of Public Roads began to provide technical assistance for building and maintaining rural post roads. ${ }^{6}$ Consequently, farmers and other rural dwellers slowly began to see the benefits of all-weather roads. By 1904, Greene County's country roads were sufficiently graveled and maintained to enable it to become the first county in Iowa to receive rural mail delivery. ${ }^{7}$

State aid was similarly foreign in concept, although Iowa briefly dabbled in plank road construction. Between 1849 and 1851 the General Assembly granted authority to build fourteen different plank roads totaling about six hundred

4. Thomas H. MacDonald, "The History and Development of Road Building in the United States," Transactions of the American Society of Civil Engineers 92 (1928), 1195-96.

5. William H. Thompson, Transportation in Iowa: A Historical Summary (Ames, 1989), 2-4.

6. The federal highway agency went through several renamings: the Office of Public Road Inquiry in 1899, the Office of Public Roads in 1905, and the Bureau of Public Roads in 1918.

7. Thomas J. Morain, Prairie Grass Roots: An Iowa Small Town in the Early Twentieth Century (Ames, 1988), 121. 
miles, but only about fifty miles were actually built. The coming of the railroads, beginning in 1855, overshadowed the need for state involvement in road building until the early twentieth century. ${ }^{8}$ Prior to the 1880 s, road and bridge building were generally regarded as practical problems of local concern, not political issues related to regional economic development or engineering challenges requiring technological mastery.

The effort to promote state aid for road construction in Iowa began in 1883 at a State Road Convention in Iowa City. Delegates to the convention organized the State Road Improvement Association and recommended adopting a policy of state aid. They also proposed the abolition of the longstanding tradition of allowing property owners to work off road taxes in labor rather than paying them in dollars. ${ }^{9}$ The following year the General Assembly gave county supervisors the authority to levy taxes for county road funds, and township trustees were authorized to consolidate several road districts into one. With that action, the State Road Improvement Association disbanded, although during the 1890s other good roads organizations arose to sustain sporadic movement toward state control. ${ }^{10}$

Iowa truly began to assume control over its roads in 1902, when the Anderson Law created the state's first highway commission, which was actually a research entity located at Iowa State College in Ames. Although the commission had little authority beyond data collection, planning, and public education, the Anderson Act nonetheless began to reverse the tradition of local control. In its first annual report the State Highway Commission advanced the case for more centralized control over road building and maintenance, pointing out that only seven counties had made any notable progress

8. John E. Brindley, "Road Legislation in Iowa," in Iowa Applied History Series, vol. 1, edited by Benjamin F. Shambaugh (Iowa City, 1912), 23-24, 36-37; Thompson, Transportation in Iowa, 5-6.

9. Brindley, "Road Legislation in Iowa," 19; George S. May, "Good Roads Organizations," Palimpsest 46 (1965), 73-74; Thompson, Transportation in Iowa, 70 .

10. Brindley, "Road Legislation in Iowa," 33; May, "Good Roads Organizations," 74-75. 
toward "permanent" road improvements. Greene County was first on a list that also included Carroll, Marshall, Lee, Clinton, Dubuque, and Scott counties. During fiscal year 1904-5 the commission began to develop technical specifications for constructing earthen roads, which constituted the vast majority of Iowa's 102,000 miles of road. The highway commission also took steps to upgrade the quality of bridges and culverts by formulating standard loadings for bridge design. ${ }^{11}$

For many years the State Highway Commission really served as the umbrella for engineer Thomas H. MacDonald's vision of the future. MacDonald, a native of Montezuma, studied engineering at Iowa State College under Anson Marston, dean of engineering. For his senior thesis MacDonald had investigated the subject of road-building in detail, comparing different types of road surfaces, querying counties and townships about the actual use of road taxes and methods of road improvement, and observing the uses to which roads were put. In the year MacDonald graduated, 1904, the Iowa legislature established the State Highway Commission and placed it under the direction of Marston and Charles F. Curtiss, dean of agriculture at Iowa State. They, in turn, launched MacDonald's career by placing him in charge of field operations. As Iowa's chief highway engineer until 1919, MacDonald campaigned for good roads, conducted numerous investigations, helped to organize a professionally staffed highway department, and began to set standards for highway construction. ${ }^{12}$

MacDonald was the consummate "hands-on" expert. In order to implement new standards for concrete structures, he was known to have put on overalls to teach local officials how to build concrete culverts. During fiscal year 1904-5, MacDonald launched the first of many annual field schools, where county engineers and road crews learned how to survey roads, operate the new King road drag, and build cul-

11. Iowa State Highway Commission, Annual Report (1905), 56; Thompson, Transportation in Iowa, 93-96.

12. Newton Fuessle, "Pulling Main Street Out of the Mud," Outlook 131 (16 August 1922), 642; Thompson, Transportation in Iowa, 76-77. 
verts. Henry Haag, then chair of the Greene County Board of Supervisors, was among the participants at the first Good Roads School. He and A. C. Steele, a Carroll County superintendent, gave a presentation titled "The Gravel Roads of Greene and Carroll Counties." MacDonald and the other commissioners also began the practice of traveling extensively to various counties. Greene County hosted MacDonald many times during the first few years the commission operated. He also introduced road demonstration projects around the state, one of which was held in Greene County in 1908. During a Farmers' Institute, the commission helped to build threequarters of a mile of properly graded earth road near Grand Junction. ${ }^{13}$

Greene County was among the first counties to meet the new professional standards. Henry Haag reported that the county built twenty new reinforced concrete slab bridges in 1906, and the Board of Supervisors authorized construction of sixteen more the following year. In its 1907-8 report, the commission noted that Greene County had "built about 175 miles of good gravel roads at a very reasonable cost." These improvements were in part attributable to abundant gravel deposits in almost every township in the county. Not only was gravel readily available, but since deposits had a minimum of sand and large rocks, the quality was immediately suitable for road surfacing. According to Dewey Schilling, a farmer who took part in road dragging and graveling, "We just drove the horses and wagon into the pit and started scooping. It would take about half an hour for three men to load a wagon to the top of the twelve-inch sides. Sometimes we would add a two-by-four extension. As the pit got deeper, we would add an extra team of horses to pull the wagon out, then unhitch the extra team for the trip to where the gravel was to be dumped, which was usually less than three miles."14

13. Fuessle, "Pulling Main Street Out of the Mud," 642; Iowa State Highway Commission, Annual Report (1905), 38-41, 48-49; ibid. (1906), 22; ibid. (1907-8), 6, 10, 39.

14. Iowa State Highway Commission, Annual Report (1906), 31-32; ibid. (1907-8), 24; Dewey Schilling, interview with Bob Ausberger, 12 December 1991 . 
By 1913, when Iowa passed a second act authorizing a separate State Highway Commission with control over all county and township road officials, forty-one states had adopted some form of state aid to highways: funds, engineering services, or convict labor. Power and authority varied widely among these state bodies from data collection to complete supervision of a comprehensive system. Compared to other states, Iowa endowed its highway commission with little real authority, but in succeeding years the legislature did significantly expand its duties. The new highway commission became the central planning office, furnishing counties with both standard plans for highway structures and detailed highway construction plans for specific road segments. This gave the state much more control over highway construction and maintenance. ${ }^{15}$

Significantly for Greene County, the membership of the new commission included James W. Holden, a Scranton farmer who had served many years as a township trustee and six terms on the Greene County Board of Supervisors. He also was a former president of the State Association of County Supervisors. Having served in these capacities, Holden was well versed on the subject of building and maintaining roads in Greene County as well as across the state. ${ }^{16}$

Although it had taken three decades to do so, Iowa finally had created the political framework necessary to carry out the ultimate goals of the good roads movement. The State Highway Commission now operated as a separate state body, still housed on the Iowa State College campus, but not subject to the college administration. Thomas MacDonald was officially elevated to the position of State Highway Engineer, a post he held until he was appointed director of the U.S. Bureau of Public Roads in 1919.17 His philosophy of shared

15. Brindley, "Road Legislation in Iowa," 42-55; Thompson, Transportation in Iowa, 71-72; Thomas R. Agg and John E. Brindley, Highway Administration and Finance (New York, 1927), 33-34.

16. Morain, Prairie Grass Roots, 120. Holden seems to have shunned the limelight, but it is worth noting that the Lincoln Highway takes an interesting jog past his farm south of Scranton.

17. Thompson, Transportation in Iowa, 76-77. 
governmental responsibilities not only shaped Iowa's highway policy, but ultimately became federal policy as well.

Ideological differences concerning the state's proper role in road construction and maintenance persisted nonetheless, particularly in rural areas. Farmers stood to lose the most, financially, from the new policies. Road taxes fell heaviest on those who owned the most property, and it was not easy for rural residents to envision the benefit of roads that were improved beyond the capabilities of the wheelbarrow-andhand-tool methods used by "volunteer" road-tax crews. As a result, they often opposed mandatory provisions of highway legislation. A highly controversial provision of Iowa's 1913 law, for instance, required county boards of supervisors to hire a county engineer who would be subject to the commission's standards of performance. Viewing this as an unwarranted intrusion of state government, many counties simply chose not to hire an engineer, and there followed a period of political struggle between those who favored the benefits of centralized control and those who clung to the tradition of local control. ${ }^{18}$

Nonetheless, between 1883 and 1913 Iowa had assembled the tools necessary to participate in creating a nascent highway system. It had a state highway commission, led by a highly capable engineer and with just enough authority to begin standardizing road design, construction, and maintenance on the local level-so long as local jurisdictions sought such assistance. What Iowa lacked was a strong mandate from the general citizenry to adopt a centralized bureaucracy and to pay for all-weather roads. Voters were split on the issue of good roads. This political disagreement has often been cast as a rural versus urban issue. But, as the Greene County story suggests, it was actually much more complex. There, support for improved roads was just as likely to come from rural property owners as from town residents.

SUCH WAS THE STATE of highway politics in Iowa when the idea for a transcontinental highway emerged. The first feasible plan came from Carl Fisher, who had inaugurated

18. Ibid., 72. 
the Indianapolis 500 in 1911 on his Indianapolis Motor Speedway. The Automobile Association of America (AAA) had proposed a transcontinental highway as early as 1902 (the same year the organization was formed), but Fisher was the first to devise an actual plan for building a road and financing it. In September 1912 Fisher invited leaders from the Indianapolis automotive industry to a dinner party, where he presented a captive audience with his plan to build a continuous coast-to-coast highway from New York to San Francisco in time for motorists to travel cross country to the Panama-Pacific Exposition in 1915. His financing plan called for raising ten million dollars in donations from those who manufactured automobiles and auto accessories and from selling memberships in an organization that shortly became known as the Lincoln Highway Association. When Frank A. Seiberling, president of Goodyear Tire and Rubber Company, immediately pledged three hundred thousand dollars toward the effort, Fisher's idea began to take hold. ${ }^{19}$

By that time, advances in technology had become one of the driving forces of the highway movement. With the invention of the internal combustion engine in 1885, and the subsequent development of steel-tube framing, ball and roller bearings, differential gearing, acetylene lamps, and pneumatic tires, approximately fifteen hundred separate automobile manufacturing companies had sprung up by World War I. Most did not survive, but nonetheless they made for an exciting period of experimentation with steam, electric, and gasoline-powered motor vehicles. By 1908 the automobile age had arrived. In that year Henry Ford placed the first Model T on the market, and William C. Durant founded General Motors. Auspiciously, the first mile of concrete-surfaced road was paved in 1908, near Detroit. Passenger car registrations jumped from about eight thousand nationwide in 1900 to more than one million in 1912 and then climbed to about 2.3 million in 1915. Iowa led the nation in adopting the automobile: car registrations increased from 799 in 1905 to 147,078 in 1915 , one for every sixteen residents. Greene County was

19. The Lincoln Highway (New York, 1935), 2; Hokanson, Lincoln Highway, 5-7. 
right in step. By 1914, car registrations had topped one thousand, one for every seventeen people. Available statistics show that farmers purchased cars as readily as town dwellers. ${ }^{20}$

The phenomenal increase in motorized vehicles did not, however, spur a quick transformation of travel conditions, for politics had not kept pace with technology. The concept of mass production had evolved, but the concept of good streets and roads that went somewhere besides uptown or around the block had not. As one historian succinctly put it, for the highway movement, unlike the railroad movement, "the rolling stock was ready before the roadbed had been designed."21

In 1900 the United States had the poorest roads of all the industrialized nations. Excepting cobbled streets, there were only two hundred miles of hard-surfaced roads in the whole country. Road conditions improved very little between then and 1912 when Fisher launched his cross-country highway plan. By that time, there were about 2.5 million miles of road in the United States, 93 percent of them unimproved dirt roads. Iowa claimed about 107,000 miles of road in 1912, and the fact that most of these miles were still referred to as "wagon" roads speaks for their condition as well as their use, Greene County's advances notwithstanding. Iowa's mud was legendary; roads were virtually impassable in bad weather. ${ }^{22}$

At the same time, railroads were approaching their peak trackage of over ten thousand miles in Iowa. ${ }^{23}$ Railroads were clearly the superior mode of transportation, integrating almost every town into a national rail network. Ironically, this

20. John B. Rae, "The Internal-Combustion Engine on Wheels," in Melvin Kranzberg and Carroll W. Pursell, Jr., Technology in Western Civilization, 2 vols. (New York, 1967), 2:122; U.S. Department of Commerce, Historical Statistics of the United States: Colonial Times to 1970, Part 2 (Washington, DC, 1975), 716; Thompson, Transportation in Iowa, 100; Morain, Prairie Grass Roots, 116.

21. Frederic L. Paxson, "The Highway Movement, 1916-1935," American Historical Review 51 (1946), 238-39.

22. Brindley, "Road Legislation in Iowa," 34; Rae, The Road and the Car in American Life, 69, fig. 4.4.

23. Ray L. Bryant, A Preliminary Guide to Iowa Railroads, 1850-1972 (n.p., 1984), shows that trackage in Iowa, including steam and electric lines, peaked at about 10,500 miles in 1915 . 
vast rail system, which a half-century earlier had stifled support for plank roads and turnpikes, now added force to the public demand for good roads. Since all commodities had to be transported to and from rail connections, good roads were imperative to sustain the regional and national systems of commerce that railroads had helped to create. Most of the raw materials that had to pass over dirt roads to reach rail connections were agricultural products, in Iowa as elsewhere. Thus the Federal Road Act of 1916, which was the first step toward programmatic federal involvement in highway construction, established a system of grants-in-aid for building farm-to-market roads as well as rural post roads to be administered by the Bureau of Public Roads in the Department of Agriculture.

In 1912, with the first federal aid for road building still four years in the future and a federal highway system even further away, Fisher's proposal to "build" a transcontinental highway was ahead of the times, both politically and practically. But Fisher was unconcerned about facilitating interstate commerce or mail delivery. Like earlier representatives from the automobile, tire, cement, and oil industries who in 1903 had formed a lobbying organization known, optimistically, as the American Road Builders' Association, Fisher was simply interested in promoting the sale of automobiles and auto products, including the carbide headlights manufactured by Prest-O-Lite, another of his business ventures.

To promote the coast-to-coast highway, Fisher gathered together a group of men who either were or would become leaders in the automotive and highway construction industries. In addition to Frank Seiberling of Goodyear Tire and Rubber, they included Henry Joy, president of Packard Company; Arthur R. Pardington, a promoter affiliated with the Indiana good roads movement; A. Y. Gowen, president of Lehigh Cement Company; Roy Chapin, president of Hudson Motor Company; Emory Clark, a banker and later head of Nash Motor Company; and John N. Willys, president of Willys-Overland Company. On July 1, 1913, this informal group officially organized the Lincoln Highway Association, dedicated to the "establishment of a continuous improved highway from the Atlantic to the Pacific, open to lawful traf- 
fic of all description without toll charges ... in memory of Abraham Lincoln."24

After two months of planning, the Lincoln Highway Association announced the route on September 10, 1913. The final decision was based on the directness of proposed roads between the terminal points of New York and San Francisco, natural advantages, and local support. Despite its notorious mud, Iowa was on the route because the Lincoln Highway Association wanted a route to connect Chicago with Omaha, gateway to the Platte River route, and because there already was a bridge across the Mississippi River at Clinton. Organized support determined the route across Iowa, and Greene County was well represented in the chief interest group, the Iowa Transcontinental Road Association (ITRA). In 1910 Jefferson banker Henry Haag was elected president of ITRA, an organization comprising road enthusiasts from towns along the Chicago \& North Western Railroad who joined together to promote an east-west highway route across Iowa. Haag, a road enthusiast who voluntarily dragged Jefferson's streets after heavy rains, also was a Greene County Supervisor, along with J. W. Holden. ${ }^{25}$ Both men served on the County Board of Supervisors at a time when road maintenance and road expenditures, always important local issues, had become policies in need of critical reexamination.

Looking to the future, the ITRA's goal was to link Iowa into an eventual cross-country highway system. The association had plenty of competition, since by 1910 there were many organizations nationwide promoting good roads, each bent on securing similar advantages for its chosen route. In that year, during Henry Haag's tenure as president, the Iowa Official Trans-Continental Route was marked. Not surprisingly, the route more or less paralleled the Chicago \& North Western Railroad and traversed Greene County. Beginning at Clinton, it passed westerly through Cedar Rapids, Tama, Marshalltown, Ames, Boone, Jefferson, and Carroll, then turned southwesterly through Denison and Logan to Council

24. The Lincoln Highway, 14-17, 23-24, 45, 63-64.

25. Morain, Prairie Grass Roots, 121-22; E. B. Stillman, Past and Present of Greene County (1907; reprint, Jefferson, 1979), 209. 


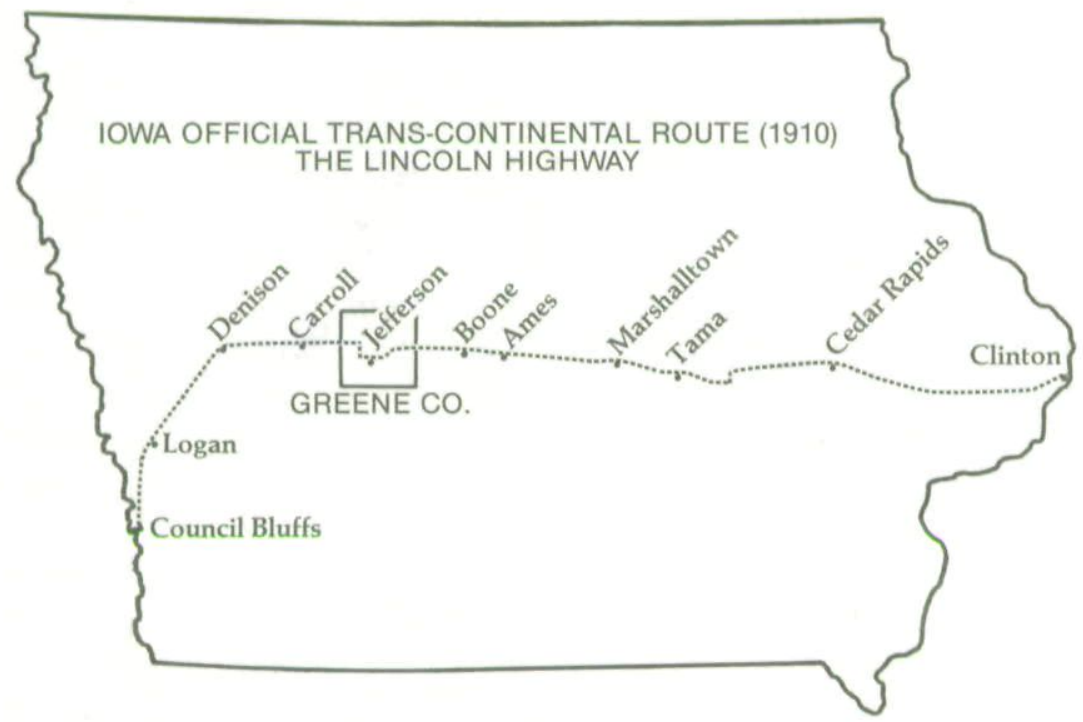

Bluffs-Omaha, a total of 358 miles across the state. Before long, this became the route most commonly used by adventuresome motorists traveling cross country through Iowa. ITRA's mission succeeded in 1913 when the Lincoln Highway Association incorporated the Iowa Official Trans-Continental Route into the first transcontinental highway. ${ }^{26}$

FRANK SEIBERLING, president of the Lincoln Highway Association, called the 1913 route "a red line on the map from New York to San Francisco. Of the total distance of 3,389 miles between these two points, less than half, or 1,598 miles, were improved, a very small part of this improvement connecting up to be of any national importance. ${ }^{\prime 27}$ The association was not content with merely laying out an organized route: promoters wanted it graded and surfaced. Gravel would help, but they were more interested in the 170,000 miles or so of hard-surfaced streets and roads that were scattered around the country-roads surfaced with brick, asphalt, bitulithic, macadam, or concrete.

26. Morain, Prairie Grass Roots, 122; Des Moines Register and Leader, 14 September 1913.

27. F. A. Seiberling, "An Open Road-The Lincoln Highway," The RoadMaker 12 (November 1918), 8. 
Citizens of Greene County worked hard to improve the route through their territory, displaying an enthusiasm that can be variously interpreted as boosterism or progressivism. For example, when the Lincoln Highway route was announced, Capt. Albert Head, from a prominent banking and real estate family that had already financially supported the road building that took place before 1913, first put up one thousand dollars toward building a reinforced concrete bridge over Buttrick's Creek, and then offered a challenge match donation to raise a total of $\$ 11,375$ dollars toward draining, grading, and graveling the Lincoln Highway through the county. George H. Gallup, father of the famous pollster, countered by promoting a plan to pave the road with concrete, a much more expensive undertaking. "Let's get the name of being the most progressive road builders in the United States by building the first 25 miles of cement road on the great Lincoln Memorial Highway," he urged in a newspaper editorial. ${ }^{28}$

Perhaps Greene County's most outspoken promoters were Paul Stillman and Victor Lovejoy, publisher and editor, respectively, of the Jefferson Bee. Both men were active in politics, and Stillman's connections reached beyond local jurisdictions; he served three terms in the Iowa House of Representatives. Equally important, both Stillman and Lovejoy believed in using the newspaper to encourage local support for projects or positions they thought benefited the community. ${ }^{29}$ In 1913 almost every issue of the newspaper carried an article promoting good roads and-once Fisher's plan was announced-the transcontinental highway. The Bee continued to extoll the benefits of improved roads for the next several years, especially in 1919, the year Greene County voted to pave a portion of the Lincoln Highway.

Rural property owners in general played a critical role in building Greene County's good roads. Despite the advantage of six creeks and rivers, lack of drainage had been an impediment to agricultural development in Greene County. Begin-

28. Stillman, Past and Present, 632; Des Moines Register and Leader, 26 September 1913; Jefferson Bee, 15 October, 5 November 1913.

29. Morain, Prairie Grass Roots, 24-25. 
ning in about 1905, Greene County farmers began to organize themselves into drainage districts containing anywhere from five hundred to four thousand acres, depending on the natural boundaries of a watershed. By 1912, tiling was well under way, and by the time the Lincoln Highway was completely paved through Greene County in 1924, more than one hundred drainage districts had been established. Hundreds of miles of tile ditches were dug by hand. ${ }^{30}$ Thus, the land through Greene County was not only fairly level; it was fairly well-drained, too. Well-drained land was crucial to building good roads. Before paving began in 1920, drain tiles had been installed parallel to the road for about half of the distance through the county; the other half of the road drainage system was completed as part of the 1920 and 1924 paving contracts. ${ }^{31}$ In addition, by 1913 most of the roads in Greene County had been graveled, an achievement that caused the Des Moines Register and Leader to proclaim them "the best all weather roads in Iowa." The county continued to attract attention as a "pioneer" in gravel road construction for the next few years. ${ }^{32}$

Early in 1913 the Greene County Board of Supervisors established an official county road system-126 miles that connected all towns. This system, as recorded on the 1913 official map of Greene County, included most of the future Lincoln Highway route, announced later that year. April 1913 saw the completion of the Eureka Bridge, a five-span, 420foot concrete arch bridge over the Raccoon River, an accom-

30. Greene County Drainage Minutes, 1905-1924, passim. Data compiled in the Sixteenth Census of the United States, Drainage of Agricultural Lands (Washington, DC, 1940) show that Greene County was among twelve counties, all in the Wisconsin Drift area, that led the state in drainage enterprises. By 1920, nearly 140,000 acres were tiled, representing 38 percent of the total land area in the county.

31. 1919 Plan and Profile of Proposed Inter-County Highway, Federal Aid Project No. 39, Greene County; 1923 Plan and Profile of Proposed Improvement on the Primary Road System, Federal Aid Project 30, Greene County, East and West of Jefferson Extending Federal Aid Project No. 39 to the County Lines, Iowa Department of Transportation, Ames.

32. Des Moines Register and Leader, 26 September 1913; Iowa State Highway Commission Service Bulletin 3 (September-October 1915), 14; ibid. 4 (July 1916), cover story. 


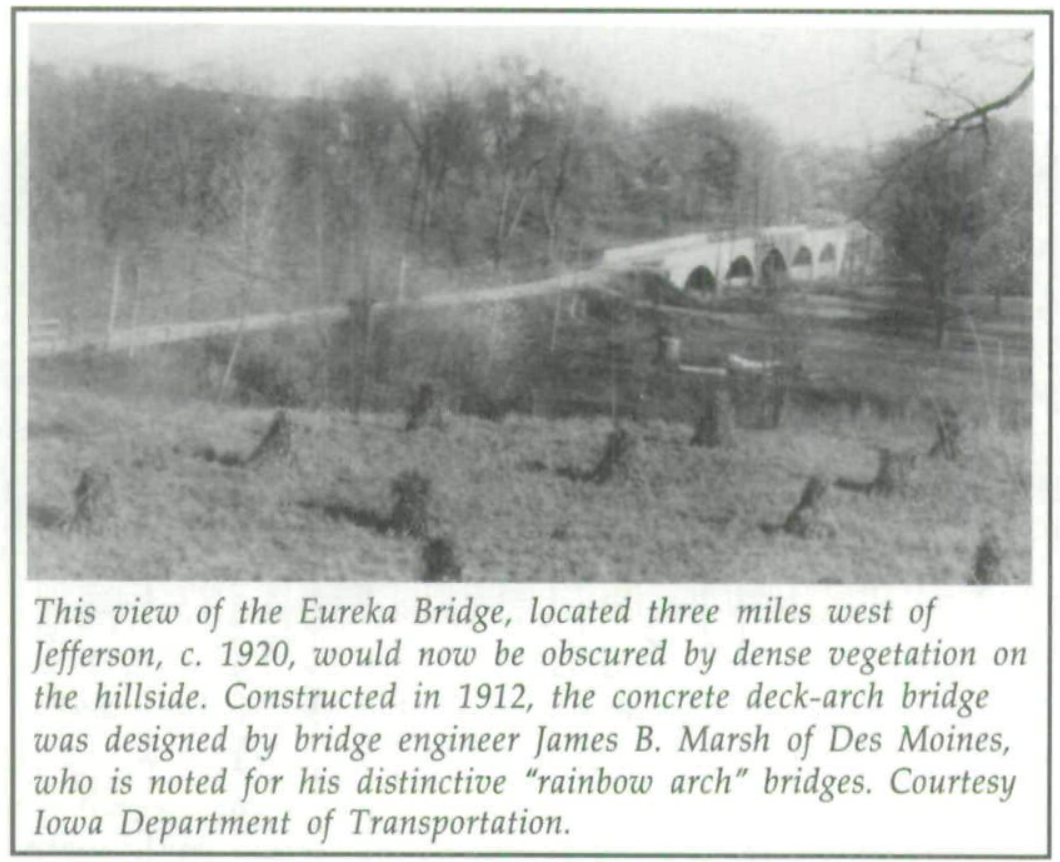

plishment that no doubt helped to secure the route. Local transcontinental highway boosters, anticipating Greene County's inclusion on the map, declared Eureka Bridge to be the largest of its kind along the entire cross-country path. ${ }^{33}$

After the route was formally announced in September 1913, a local campaign to raise matching funds for highway construction got under way. Promotional meetings were staged in Jefferson, Scranton, and Grand Junction. Thomas MacDonald appeared as the featured speaker at the Jefferson meeting, after which various members of the audience pledged a total of twenty-five hundred dollars in subscriptions. E. B. Wilson and Victor Lovejoy pitched the highway plan to a large audience at Scranton, where a band provided additionál entertainment. ${ }^{34}$

With the initial festivities aside, local citizens got down to work. In February 1914 a committee representing the Lincoln Highway in Greene County asked the Board of Supervisors to allocate $\$ 20,000$ for grading and preparing the

33. Bee, 26 January, 2 April, 21 May 1913.

34. Bee, 5 November 1913. 


\section{THE LINCOLN HIGHWAY}

Realizing the benefit of the Lincoln Highway and desiring to assist in meeting the requirements whereby the Board of Supervisors will expend \$15, ooo on said Highway during the year $1914, I$ hereby subscribe the sum of Juenty fine + no $10^{\circ}$ DOLLARS same to be paid on of before March 25,1914 .

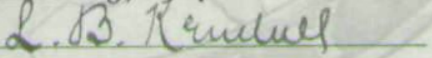

L. B. Kendall submitted this Lincoln Highway subscription certificate during Greene County's 1914 fund-raising campaign. Courtesy Greene County Historical Museum.

road for hard surfacing. The board agreed to spend $\$ 15,000$ if an additional $\$ 5,000$ could be raised from private citizens. At the time, the local committee was operating on the assumption that the national Lincoln Highway Association would raise enough money by the end of the year to pay for paving the entire route. That plan never materialized, but local supporters nonetheless raised the required $\$ 5,000$ from subscriptions, and Greene County took steps to prepare the thirty miles of road under its jurisdiction. By the end of the year, Greene County had four hundred miles of graveled road, and the Head Memorial Bridge over Buttrick's Creek, a two-span concrete arch bridge, was open for travel. Greene County was among five counties in Iowa that spent a reported total of $\$ 140,000$ in 1914 to improve the Lincoln Highway route. ${ }^{35}$

35. Minutes of the Greene County Board of Supervisors, 16 February 1914; Bee, 18 February 1914; Bulletin of the Iowa State Highway Commission Service 2 (February 1914), 3-4; ibid. (October 1914), 10-11; ibid. (November 1914), 3, 15; Collier's, 9 January 1915. 
Improving the highway was not without its snags, however. The route through Greene County did not align with the route adopted by Boone County, its eastern neighbor, so in 1914 Greene County agreed to adjust its route east of Grand Junction so the two roads would meet squarely at the county line. This realignment also eliminated two railroad crossings, thus satisfying safety concerns that the highway commission had begun to raise. ${ }^{36}$

Despite the initial flurry of activity, the national Lincoln Highway Association abandoned its overly ambitious plan of paving the whole route within a year. Although the 1914 AAA guide book and the 1915 official Lincoln Highway guide provided motorists with fairly specific written directions (there was no such thing as a detailed map yet), those who were bound for the Panama-Pacific Exposition in 1915 quickly discovered that most of the route west of Chicago was well marked but still in a state of "natural" road. Graded and graveled was as good as it got. Henry Joy, president of the Lincoln Highway Association singled out Iowa's roads as among the worst. "Today, in the rich state of Iowa," he said, "not a wheel turns outside the paved streets of her cities during or for sometime after the frequent heavy rains. Every farm is isolated. Social intercourse ceases. School attendance is impossible. Transportation is at a standstill." ${ }^{137}$

36. Bee, 25 February 1914; Thompson, Transportation in Iowa, 98-99. Railroads, which held the vehicular right-of-way by virtue of size and seniority, initiated their own safety campaign. Steadily increasing traffic on all roads and highways caused railroad companies considerable concern because motorists did not automatically adopt the habit of stopping-or even slowing down-at rail crossings. A rash of fatalities finally prompted railroad companies to enlist the support of newspapers to remind motorists to "Stop, Look, and Listen." On October 4, 1916 the Jefferson Bee published an open letter from the Illinois Central Railroad pointing out that in a three-month period 18 people had been killed and 36 injured at rail crossings in Iowa and Illinois. Calculating that it would cost the company more than $\$ 215$ million dollars to separate the grade at its eight thousand crossings on the system, "nearly twice the capital stock of the company," Illinois Central urged the motoring public to exercise caution before passing over any railway crossing and especially to heed crossing gates, warning bells, and engine signals. It was easier to adjust the highway route wherever there were local problems than to fight railroad companies.

37. Quoted in The Lincoln Highway, 245. 


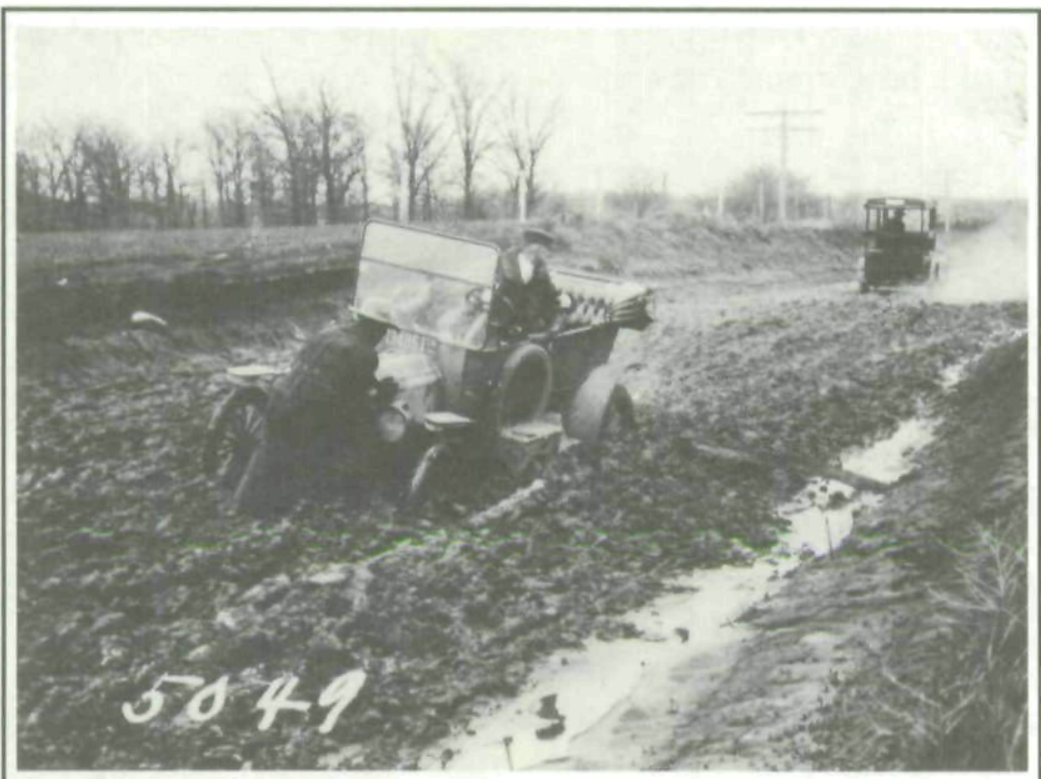

For motorists, Iowa was synonymous with "gumbo" in the pre-pavement days. Notice that this section of the Nevada Road, east of Ames in Story County, appears to be entirely below the natural grade. Photo c. 1917, courtesy Iowa Department of Transportation.

On the positive side, by year's end the thirteen Iowa counties through which the Lincoln Highway passed had spent a total of $\$ 250,000$ to prepare the roadbed, and practically all of the bridges along the route were of reinforced concrete construction. ${ }^{38}$ Highway promoters in Greene County remained optimistic. In December 1915 John Thompson and Harvey Strong engaged in a road race across Iowa to test the quality of the Lincoln Highway against that of the River to River Route, which ran from Davenport to Council Bluffs. Thompson, driving the Lincoln Highway, won the race "in spite of the many imperfections in the road," reported Victor

38. Literary Digest, 27 November 1915. An article in the NovemberDecember 1917 issue of the Iowa State Highway Commission Service Bulletin (p. 12) quotes a Lincoln Highway official as stating that Iowa was a leader in the character and quality of its bridges. 
Lovejoy, editor of the Bee. Lovejoy hoped those imperfections would be corrected in "the next year or two." 39

THE EFFORTS of the Lincoln Highway Association and of local boosters stirred interest in a federal highway system, but it would require the active involvement and financial commitment of the federal and state governments to make the system a reality. The 1916 Federal Road Act eventually provided the impetus to renew local efforts. That act provided an appropriation of $\$ 75$ million over a five-year period to be distributed among states with established highway departments and designated road systems. States also were to match federal funds on a $50-50$ basis. ${ }^{40}$

Passage of the 1916 act closed the first chapter on a serious debate concerning federal expenditures to support highway construction. Rural districts had opposed road improvement measures that would place a heavier burden on their property owners. At a time when relatively few people owned automobiles, others questioned the need for large expenditures of public funds to accommodate what was still considered a luxury. On one side stood the National Highway Association, the Automobile Association of America, and the automobile industry organized as the National Automobile Chamber of Commerce, all advocating a federal highway commission and federal construction of an interstate highway network. On the other side stood Logan Page, director of the USDA's Office of Public Roads, and state highway engineers (mostly from the Midwest) working under an umbrella organization known as the American Association for Highway Improvement. The latter coalition argued for federal aid to cooperating state highway departments. Page, in fact, is acknowledged as the real architect of the policy that emerged with passage of the act in 1916, which provided federal funds, up to ten thousand dollars per mile, to match state

39. Bee, 8 December 1915 .

40. Congress authorized an additional $\$ 200$ million for fiscal years 19191920 and 1920-1921. See Thomas H. MacDonald, "When Uncle Sam Goes On the Road," The Independent 102 (June 19-26, 1920), 385, 418. 
expenditures for highway construction. ${ }^{41}$ That policy clearly defined a limited role for the federal government while strengthening the trend toward centralized control by state agencies.

The Iowa General Assembly accepted these provisions in 1917 , but it took another two years before a state highway system was designated. Opposition to centralized control remained strong across Iowa; and despite the obvious benefits of paved roads, the potential costs, both financial and political, gave most county supervisors headaches. Concrete paved roads cost at least thirty thousand dollars per mile, well beyond the means of most counties. In 1919, when the State Highway Commission finished selecting the 6,500 miles to be incorporated into a designated system, legislators judiciously chose to call it the "Primary Road System"; had the name suggested either state control or paving, it probably would not have been approved. ${ }^{42}$ The Lincoln Highway subsequently became Highway No. 6 on the Primary Road System.

In 1916, the year before the state highway system was set, the Greene County Board of Supervisors authorized the County Auditor to apply for federal aid in order to continue improving the Lincoln Highway. ${ }^{43}$ Initially, supervisors envisioned paving the entire highway through the county, but it soon became clear that state funds would be distributed as widely as possible, so the supervisors scaled back their plans. Consequently, when the Primary Road System finally was announced in 1919, the county immediately applied for federal aid to pave six-and-a-half miles of the Lincoln Highway, extending equal distances east and west of the county seat, Jefferson. On April 2, 1919, the Bee announced, "Greene County will be the FIRST county in Iowa to accept Federal Aid for paving the country roads." In so doing, Greene County

41. Seely, Building the American Highway System, 37-45; Paxson, "The Highway Movement," 342-43.

42. Bee, 29 November 1916; Thompson, Transportation in Iowa, 73.

43. Minutes of the Greene County Board of Supervisors, 1 November 1916 , show that Greene County pledged $\$ 25,000$ to roads, a sum to be matched by $\$ 25,000$ in federal monies. 
joined the vanguard in terms of state highway construction. Although the Bureau of Public Roads had approved 775 state highway projects between 1916 and the end of 1918, the war in Europe had drained away materials as well as federal and state engineers who were needed by the army. As a result, only a paltry thirteen miles of federal-aid highways had been completed nationwide by March 1919. That same year, the Bureau of Public Roads approved nearly 1,200 projects nationwide, and the following year it committed $\$ 86$ million in federal funds for 1,286 projects. The year 1919 thus marked the effective start of federal-aid highway construction. ${ }^{44}$

Several Iowa counties received federal aid for paving in 1919; however, Greene County's stretch and the "seedling mile" east of Cedar Rapids, a demonstration project funded by the Lincoln Highway Association, remained the only concrete-paved surfaces along the route through the state until 1924. In part, that was because initially the maximum federal match toward highway construction was ten thousand dollars per mile, only one-third of the cost of concrete paving, so local communities that wanted paved roads had to make up a sizeable difference. That gave Greene County a decided advantage, because much of the road preparation costs had already been absorbed. Between 1905 and 1919 , Greene County had spent nearly two million dollars on drainage projects, and nearly all of its designated "primary roads" were ready for paving. ${ }^{45}$

In addition, county residents were overwhelmingly in favor of paving roads. They had the opportunity to give tangible evidence of their support in 1919 when the Board of Supervisors placed on the ballot a one-million-dollar bond issue to finance paving the entire primary road system in the county. Prior to the election, the Board of Supervisors appointed a committee to tour Wisconsin, Michigan, and Illi-

44. Bee, 2 April 1919; Bruce E. Seely, Building the American Highway System: Engineers as Policy Makers (Philadelphia, 1987), 49-51, 55. MacDonald (The Independent, 1920) reported that by May 1, 1920, the federal government had subsidized 13,540 miles of actual road construction in the U.S.

45. Seely, Building the American Highway System, 49; MacDonald, "The History and Development of Road Building," 1201; Bee, 11 June 1919. 
nois to inspect concrete-paved roads in those states. The committee "came home convinced that concrete roads ... are practicable, durable, and a good investment for the people of Greene County." 46

Then, just three days before the election, the celebrated Motor Transport Corps traveling the Lincoln Highway encamped at the county fairgrounds in Jefferson. The 280 men in the army convoy, which included a young lieutenant colonel named Dwight D. Eisenhower, were treated to hot showers at the Jefferson Cement plant, a banquet at the country club, and entertainment by the Goodyear Tire Band, which traveled with the convoy courtesy of Frank A. Seiberling. Meanwhile, local auto enthusiasts inspected the Cadillacs, Franklins, Packards, and Dodge cars as well as the ambulances, trucks, and tanks that made up the motor transport fleet. ${ }^{47}$

The convoy traveled for official purposes: to gather data on vehicle performance, to demonstrate the need for a comprehensive system of national highways, and to inspect the Lincoln Highway for suitability as a military defense highway, since it was the most improved transcontinental route in existence in 1919. World War I had demonstrated to some, most notably the automobile industry, that the United States needed a highly coordinated transportation system in order to provide adequate national defense. ${ }^{48}$ At the same time, the wartime diversion of materials precluded the implementation of approved highway projects. Critics who wanted control centralized in a federal highway commission seized the initiative and blamed the Bureau of Public Roads for obstructing

46. Bee, 23 July 1919.

47. Bee, 25 June, 16 July, 30 July 1919.

48. World War I marked the beginning of automobile industry executives participating in national defense planning. Howard E. Coffin, vice president and chief engineer at Hudson Motor Car Company, chaired the Council for National Defense. Coffin brought in two other industry leaders-Alfred E. Reeves, head of the National Automobile Chamber of Commerce, and Roy Chapin, president of Hudson-to head important committees of the council. The automobile industry played an important role in coordinating highway transport during World War I, and as a result, began to view national defense as a means of boosting industry production. See St. Clair, Motorization of American Cities, 136-43. 
progress. As a result, the debate leading up to the 1916 highway act reemerged after the war. In the midst of the renewed debate, Logan Page, chief defender of a limited federal involvement, died. Shortly thereafter, in April 1919, the army truck convoy began its celebrated journey from Washington, D.C., to San Francisco, giving the automobile industry, the U.S. Chamber of Commerce, and other advocates of a national highway commission ample opportunity to publicize their position. ${ }^{49}$

Moving on a strict schedule, the entourage generally held course on the Lincoln Highway, although there was a short detour from the official route to visit Glidden, home of Merle D. Hay, the first Iowan killed in the war. Highway promoters staged a grand celebration in Jefferson. Officials from the Lincoln Highway Association took their turns at the podium, and Dr. J. K. Johnson, Sr., one of the strongest local advocates, delivered a timely address in support of concrete paving. Greene County voters thus were well primed for the paving-bond election. On July 28, 1919, they voted three-toone in favor of the bond issue. ${ }^{50}$

Despite the commitment to pave the entire primary sytem in the county, only six-and-a-half miles were paved that year. The work entailed major efforts to eliminate two hazardous spots in the road. A zigzag at Buttrick's Creek, east of Jefferson, became a smooth S-curve incorporating the new Head Memorial Bridge. At Danger Hill, on the west side of the Raccoon River, a steep grade was reduced to six percent, producing a fifteen-foot road cut, considered "spectacular" for Iowa at the time. The highway commission photographed the grading at Danger Hill, and local residents routinely drove out to watch the men at work. Onlookers could appreciate the irony of the scene: teams of horses and mules shaping a

49. Seely, Building the American Highway System, 51-53; Paxson, "The Highway Movement," 244-45.

50. Peter T. Harstad and Diana J. Fox, "Dusty Doughboys on the Lincoln Highway: The 1919 Army Convoy in Iowa," Palimpsest 56 (1975), 78; U.S. War Department, Annual Report (1920), 1789-90; Lincoln Highway Association, A Picture of Progress on the Lincoln Way (Detroit, 1920), 13-14; "Transport Train Proving Tremendous Success," The Lincoln Highway Forum 2 (15 August 1919); Bee, 2 and 30 July 1919. 


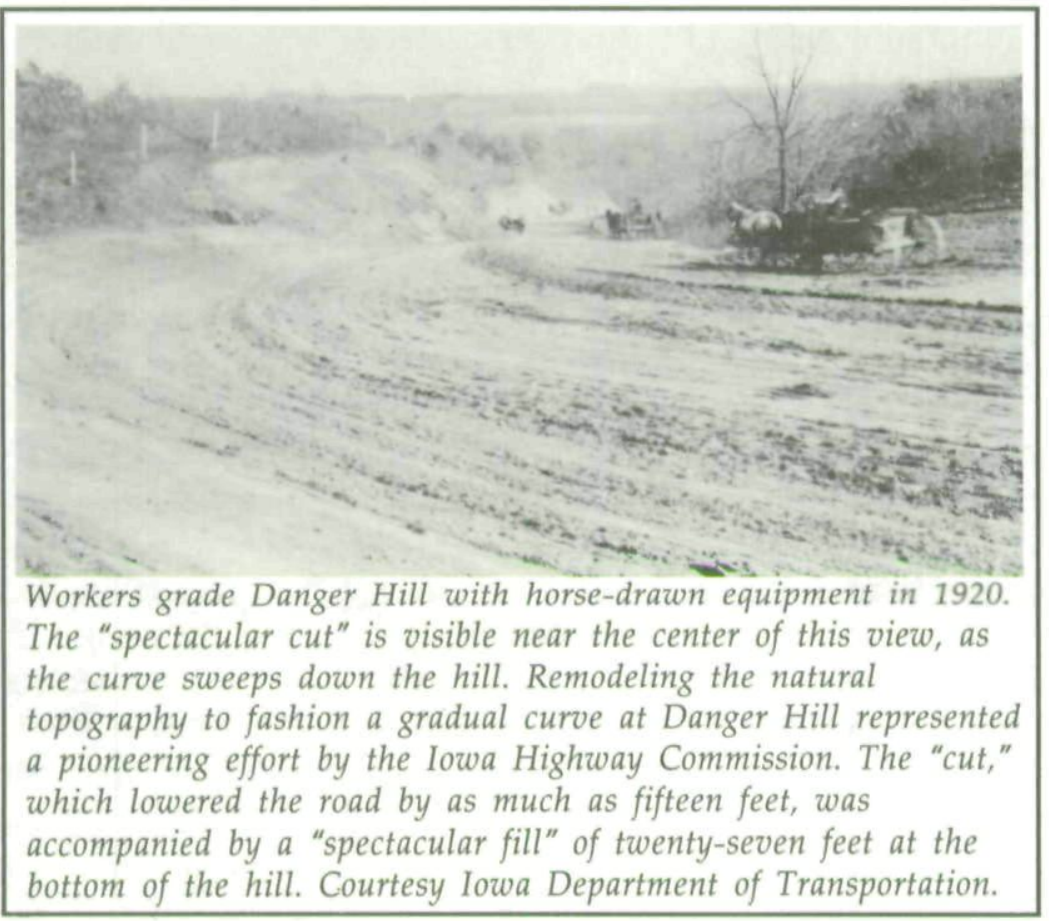

state-of-the-art road for the newfangled automobile. "The first time they took Danger Hill down was with horses, mules, and Fresnos - that was a two-wheel outfit with a handle to raise the load after it was loaded.... Everybody went out to watch. It was really a spectacle." ${ }^{\prime 51}$

As things turned out, a smaller-scale project was for the best; paving a road with concrete was a much more difficult task than it seemed. In the first place, road paving took carloads of cement, not just bags; and it took piles of sand and gravel, not wagonloads hauled from small local deposits. In order to handle the quantities of materials needed, the contractor, F. E. Marsh Co. of Jefferson, purchased a ten-acre storage site near the Jefferson Cement Products Co. and constructed a special switch track from the Milwaukee Road to the cement plant and storage site. Preparations were moving

51. Bee, 15 October 1919; Iowa State Highway Commission Service Bulletin 9 (August-September 1920), 8; Dr. J. K. Johnson, interview with Bob Ausberger, 14 September 1991. 
along smoothly until the first carloads of cement arrived. Shipped loose in open cars in order to avoid the time and expense of handling sacks, the cement passed through a rainstorm and arrived with a five-inch crust. ${ }^{52}$

After about six months of planning and delays, a fleet of fourteen dump trucks began hauling the premixed sand, gravel, and cement to the paving site, where it was mixed with water from Hardin Creek. The first load of concrete was poured onto the road on September 25, 1920, at a point about one hundred yards west of the Hardin Creek bridge. Greene County cheered this as the first concrete paving on the rural Lincoln Highway route in Iowa, ignoring a two-mile segment near Cedar Rapids, paved in 1919, because it was not on the "official" highway route when the paving was done. Pouring the concrete presented some new challenges. Workers learned that they had to adjust the consistency of the concrete for pouring on slopes. Dr. J. K. Johnson, Jr., who worked with County Engineer S. J. Melson as an inspector, recalled that when the paving was done on the western outskirts of Jefferson, "they poured it too wet and in front of the hospital it crept downhill. They worked until midnight to try and get it pulled back. That section was always rough." ${ }^{\prime 53}$

Practical problems aside, the section, when completed, became 6.5 of the 422 miles of concrete road then in existence along the entire Lincoln Highway route. Out of a total 3,305 transcontinental miles (at that time), 2,863 of them were considered to be "improved" roads, but the type of surfacing material varied widely among concrete, brick, bitulithic, macadam, asphalt, creosote block, granite block, and graded gravel. Most of the permanently hard-surfaced roads still lay east of the Mississippi. ${ }^{54}$

Greene County took to heart "The Basic Appeal" sent out by the Lincoln Highway Association in 1913, when it called upon "all the people" to accept "the patriotic burden of establishing, broadening, straightening, maintaining, and beautify-

52. Bee, 21 April 1920, 17 May 1920.

53. Bee, 29 September 1920; Dr. J. K. Johnson, interview with Bob Ausberger, 14 September 1991.

54. Bee, 25 January 1921. 
ing" a highway dedicated to the "Great Martyred Patriot." The county was one of five in Iowa that voted in 1919 to begin paving the highway, leading the Lincoln Highway Association to declare that Iowa was now on the "progressive list" of states. Even so, states east of the Great River-New Jersey, Pennsylvania, Ohio, Indiana, and Illinois-had spent twothirds of the nearly twelve million dollars invested in the road as of 1920. West of the Mississippi, only Wyoming and Utah had spent less than Iowa. ${ }^{55}$

THE FEDERAL AID HIGHWAY ACT OF 1921 marked the beginning of a sustained federal-aid highway program. It was largely the work of Thomas H. MacDonald, who succeeded Logan Page as head of the Bureau of Public Roads (BPR) in 1919. MacDonald had earned high respect among his fellow highway engineers during his fifteen years as Iowa's chief highway engineer, where he had both supported and monitored the initiative displayed by Greene County residents to improve their roads, including the Lincoln Highway. A longtime supporter of federal aid rather than federal control, the BPR under his direction began to build a stronger federal-state partnership. By demonstrating that a federal-aid system could provide an effective mechanism to build highways efficiently, MacDonald mollified the BPR's former critics and solidified support behind continuing a cooperative federal-state highway program. When Congress passed the Federal Highway Act of 1921, the federal-aid policy originally designed by Logan Page emerged even stronger. ${ }^{56}$

For Greene County, the new law meant that it could complete its paving plan. By authorizing state appropriations for several years in advance, the act made it possible to phase projects with some confidence that funding would be available through to completion. Iowa's Primary Road System met all stipulated requirements under the new law. From the state

55. Lincoln Highway Association, A Picture of Progress on the Lincoln Way, $5,15,20-22$.

56. Seely, Building the American Highway System, 54-65. See Thompson, Transportation in Iowa, 76-78, for a brief account of MacDonald's major accomplishments as state highway engineer from 1904 to 1919. 
system, the Lincoln Highway, the Jefferson Highway (U.S. 65 and 69), the River to River Route (U.S. 6), and several others were incorporated into the new federal interstate highway system created by the law. ${ }^{57}$ It would be several years, however, before motorists were aware that they were traveling on "federal" highways.

After representatives from the towns of Grand Junction and Scranton appeared before the Greene County Board of Supervisors in May 1923 to request primary road funds for paving the Lincoln Highway through their corporate limits, there was new talk of completing the whole paving job, and the county subsequently applied to the State Highway Commission for additional aid. In November 1923 the Board of Supervisors awarded the paving contract to Empire Construction Company of Des Moines. By late 1924, the entire thirty miles was concrete surfaced, making Greene County the first in Iowa to complete this undertaking. ${ }^{58}$

Langwith's 1925 Motor Trails Map of Iowa reveals the status of the Lincoln Highway a year later. By then, motorists could travel paved road across Clinton County, from Mt. Vernon to Cedar Rapids, short distances on either side of Belle Plaine and Marshalltown, and across Greene County. The rest of the highway was a mixture of graveled roads and improved and unimproved dirt roads. Iowa had barely started to lift itself out of the mud, but thanks to the combined efforts of local citizens and the state and federal governments, it was smooth traveling on the Lincoln Highway through Greene County.

IN ONE OF THOSE ODD TWISTS OF FATE, the very highway system that the Lincoln Highway Association helped to create also rendered the organization unnecessary. The association nonetheless remained active for a few more years, working with state highway departments to promote hard surfacing along the entire route and to eliminate grade cross-

57. Seely, Building the American Highway System, 59-62; Thompson, Transportation in Iowa, 136, 144-46.

58. Bee, 3 October 1923, 21 November 1923, 10 September 1924, 22 October 1924 . 
ings; providing travelers with guides, maps, and other paraphernalia; and keeping track of highway statistics. In 1913, the year the Lincoln Highway was announced, fewer than 150 cars crossed the United States on the route. A decade later, 25,000 automobiles carried tourists from the Atlantic to the Pacific. By 1924, the Lincoln Highway was no longer a mere series of connected trails. Its 3,143 official miles began to resemble fully the Main Street of America its promoters had envisioned. By the end of 1926 , more than $\$ 89$ million had been spent on construction and maintenance by the eleven states the highway traversed. ${ }^{59}$ If Greene County's experience is any guide, a considerable portion of the funds came from local coffers.

The creation of an interstate highway system eventually led to a uniform system of numbering, which replaced the maze of markers and signs erected by competing road associations. Iowa alone had sixty-four registered trails and highways, each of them sponsored by a different organization issuing guidebooks and identifying its roads with distinctive colors and symbols. The numbering scheme adopted for the new federal highway system in the mid-1920s left the Lincoln Highway's identity splintered into U.S. routes 1, 30, $30 \mathrm{~N}, 30 \mathrm{~S}, 530,40$, and 50. Iowa State Primary Road No. 6 became U.S. 30. New rules banned all nongovernment road signs, and the old highway markers began to come down. ${ }^{60}$ As one of its last official acts, the Lincoln Highway Association petitioned the American Association of State Highway Officials in 1928 for permission to place small concrete

59. Lincoln Highway Guide, 1924, p. 109; Gael S. Hoag, Lincoln Highway Association Secretary, to Officers, Directors, and Founders, memorandum of 28 March 1927, copy in possession of Bob and Joyce Ausberger, Jefferson, Iowa.

60. There were two markers for the Lincoln Highway. The first consisted of red, white, and blue bands painted on poles, fence posts, stakes, rocks, or other inanimate objects. In 1920 the markers were upgraded with painted metal or porcelain signs in red, white, and blue with the words Lincoln Highway and the letter $L$ in a white field. See Tony Vorsten, "The History of the Lincoln Highway," paper presented at the 1974 annual meeting of the Iowa Highway 30 Association, typescript located at State Historical Society of Iowa, Iowa City. See also The Lincoln Highway, 21016. None of these markers remain along the highway. 


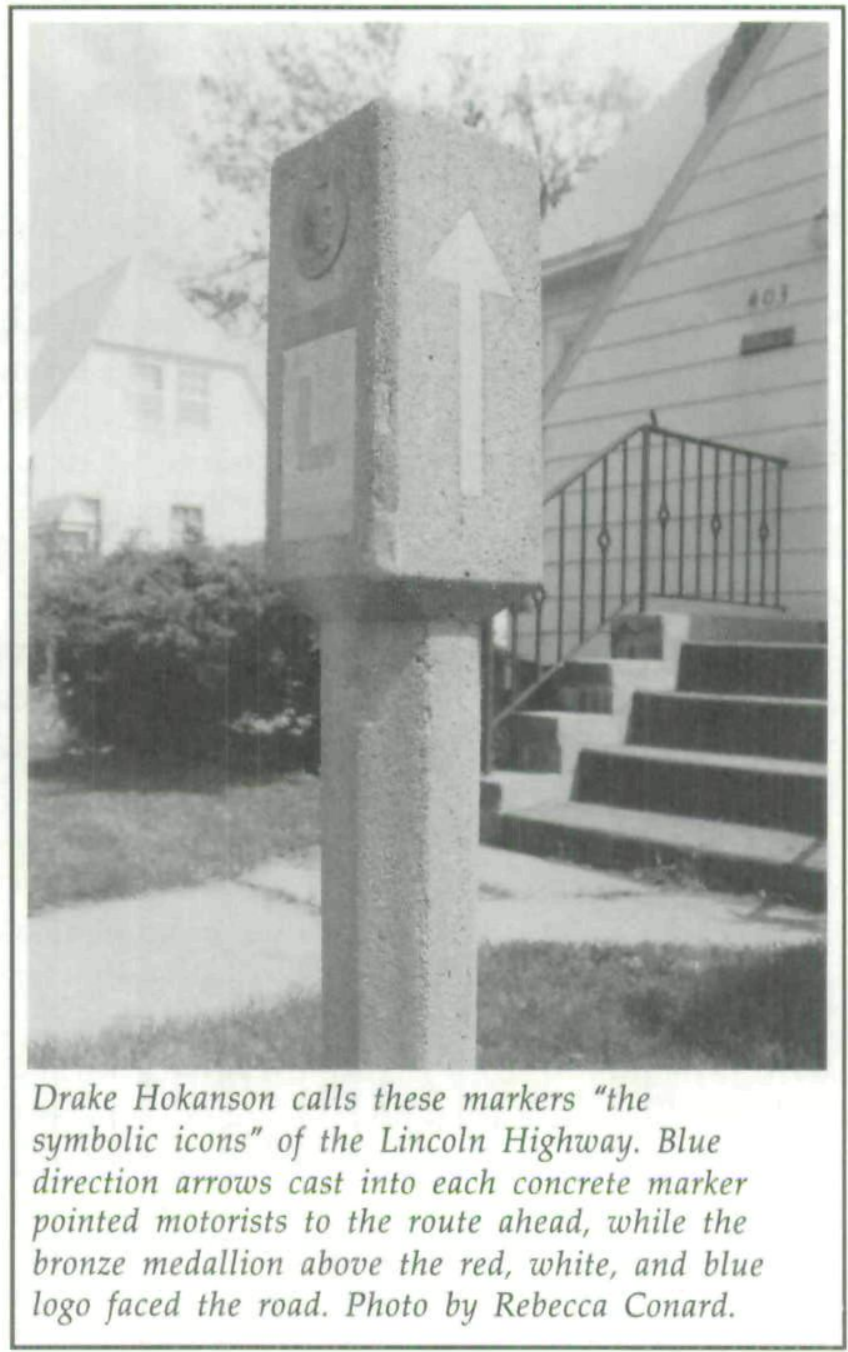

posts along the route. With help from supporters in the cement industry, the association had about three thousand markers cast, each ornamented with a bronze medallion inscribed "This highway dedicated to Abraham Lincoln" around a likeness of its namesake. On September 1, 1928, Boy Scout troops across America, working with the association, installed the markers at planned locations approximately one mile apart. ${ }^{61}$

61. The Lincoln Highway, 216-21. 
So the Lincoln Highway remained a specially marked road for those who cared to know. After the interstate system took on its safe but sterile four-lane divided form, the Lincoln Highway became one of the cherished "blue" highways, so named for the blue AAA automobile guides that once accompanied travelers across the country. Gradually, though, the memorial markers disappeared from the highway's side, some the victims of carelessness, some of vandalism, some of road improvements, and some of roadside development. Now and then concerned citizens would relocate isolated markers to parks, museums, gardens, or private yards in order to rescue them from oblivion. Few of the memorial markers remain, and only a dozen or so are reportedly in their original locations.

Today, the legacy of citizen involvement in building the Lincoln Highway is most evident in a bronze statue of Abraham Lincoln standing on the Greene County courthouse square, adjacent to the highway as it passes through Jefferson. Donated by lawyer E. B. Wilson and his wife, Minnie, the statue was dedicated specifically to the highway and the memory of Abraham Lincoln at the height of World War I, when the nation steeped itself in patriotic symbols. Wilson also served as the Western State Counsel (Iowa) of the Lincoln Highway Association. Citizens erected assorted memorials along the entire route of the Lincoln Highway during the early years, but the Lincoln Highway Association called this statue of Lincoln "the finest of them all."62

Countywide, the legacy also lives on in several private property markers along the route, particularly in two monuments that bore busts of Lincoln. Both were erected by James E. Moss, a prominent Greene County farmer and Civil War veteran, and a member of the Lincoln Highway Association. In a 1921 letter to the association he proudly wrote, "I am glad to be able to pay [my annual dues] as the Lincoln Highway will be the greatest memorial in the world in memory of one of our greatest citizens, and of the greatest world power. I am one of the Civil War soldiers. Lost a foot at Mission Ridge-glad to be yet alive. Will be one, if not the

62. Ibid., 224. 


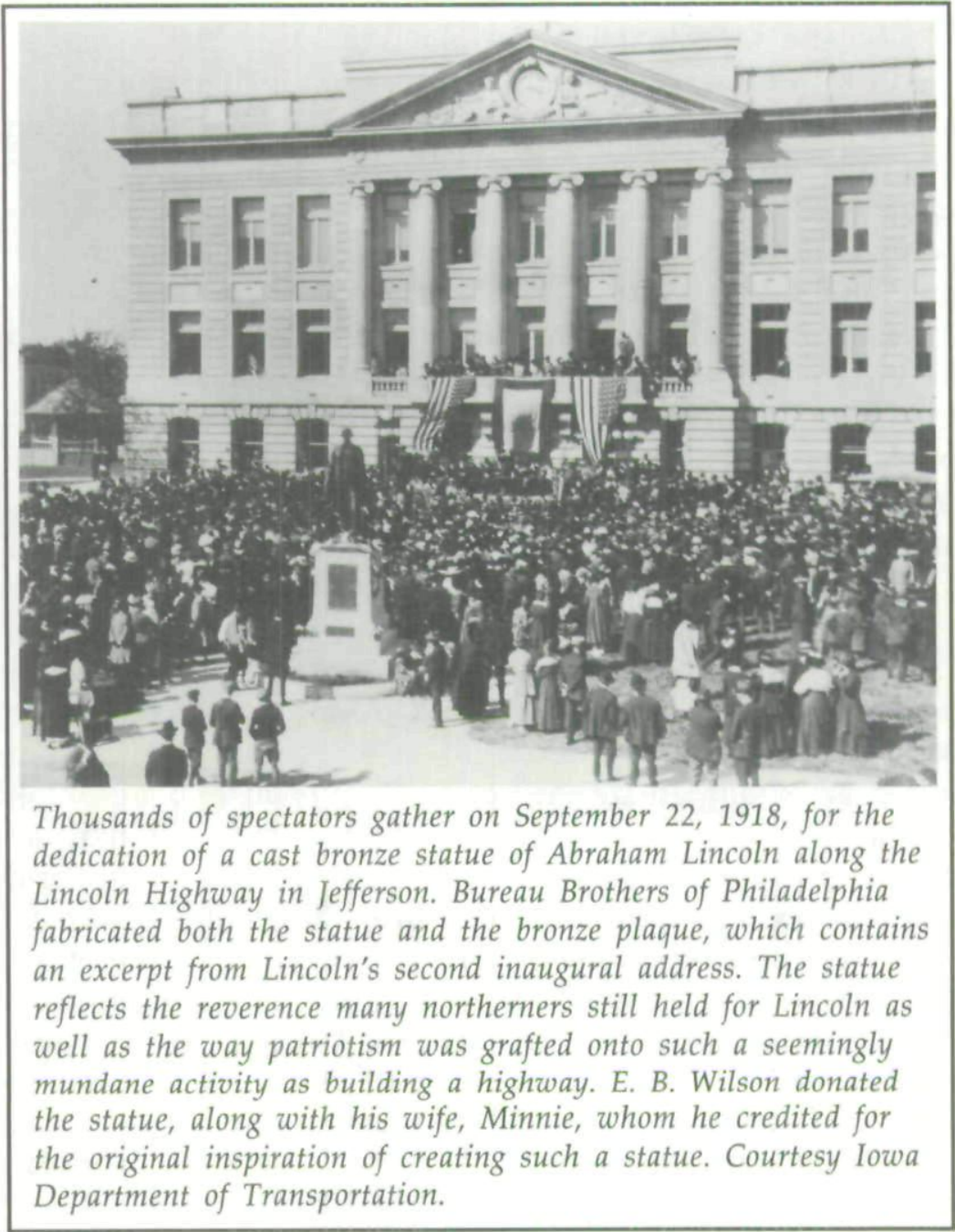

heaviest tax payer towards paving the Lincoln Highway, having two miles of the route through my farm in Greene County, Iowa." 63

A more significant legacy was the federal-aid highway policy of federal and state cooperation, relying on local initia-

63. Letter from James E. Moss to the Lincoln Highway Association, Peter T. Harstad Manuscript Files, BL93, State Historical Society of Iowa, Iowa City. See also Peter T. Harstad and Diana J. Fox, "Dusty Doughboys on the Lincoln Highway: The 1919 Army Convoy in Iowa," Palimpsest 56 (1975), 84. 


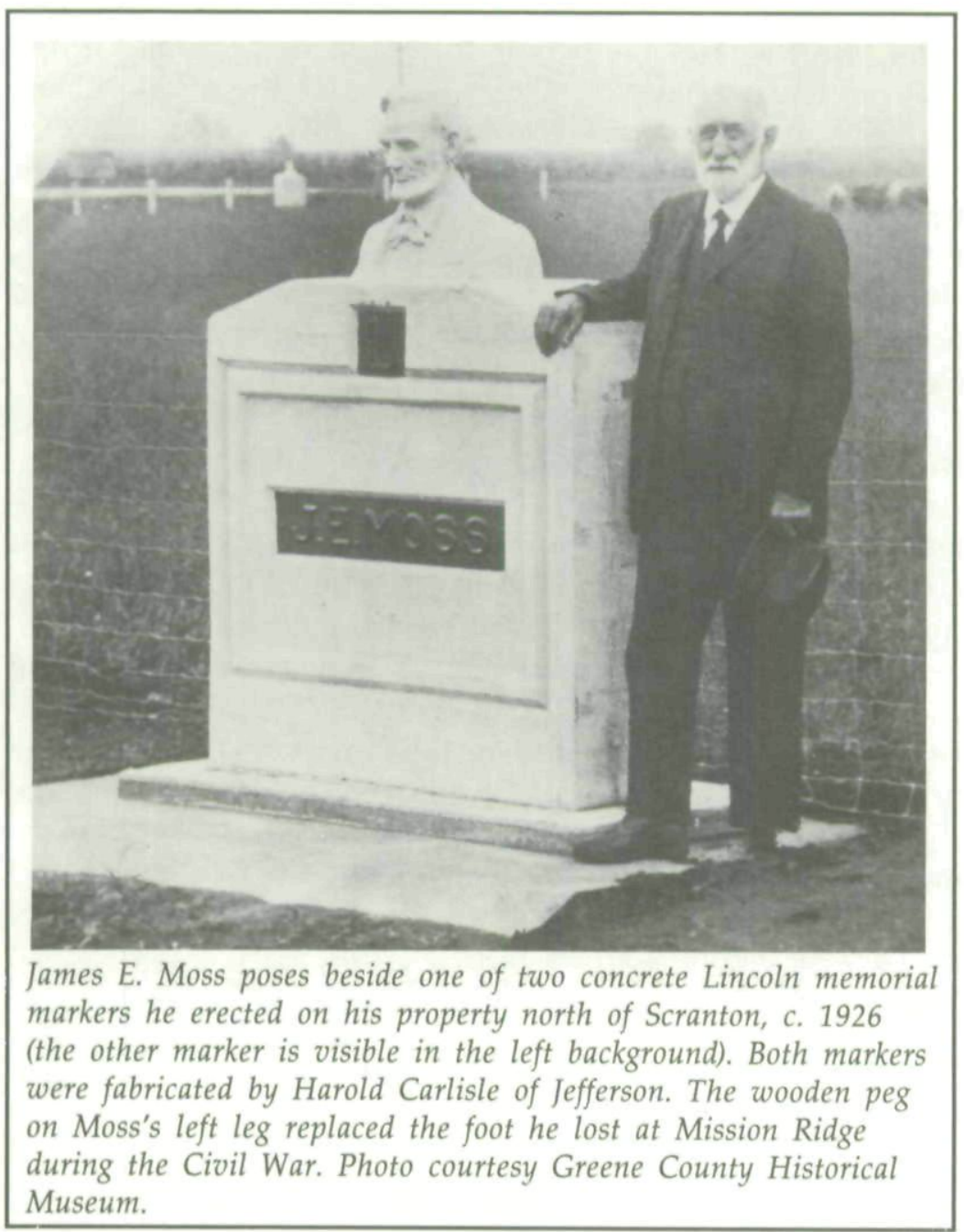

tive. The possibilities of this partnership approach were effectively demonstrated in the building of the Lincoln Highway in Greene County. The federal government set standards and guidelines, provided technical assistance and political leadership, and channeled federal aid. The state highway department assumed responsibility for managing actual road construction. The local community contributed to the construction costs, thereby placing some of the financial burden on those who used and benefited most from highway improvements in their immediate area. Greene County represented 
what probably was happening in thousands of locales across the country, if we are to take at face value the total of 2,986 highway projects approved or under way by the end of $1920 .{ }^{64}$ Local initiative, whether in Greene County or half a continent away, surely demonstrated that local communities, working with state engineers, could best decide which roads should be improved, and when. Local initiative, in short, had proved vital to the development of Iowa's highway system, evidence that a partnership approach could and would work.

In addition to the monuments it inspired and the highway policy it validated, the legacy of the Lincoln Highway in Greene County lives on the old "blue highway" itself, which retains much of its early twentieth-century character through Greene County. The road hugs the terrain and squeezes through narrow bridges. Ghost-like abandoned sections linger near curves that were realigned and regraded when the road was paved in the early 1920 s. Local citizens have worked to identify and preserve the remaining threads of the original highway. Just as local initiative helped to build the road, so too has local initiative rescued it from slow but certain oblivion.

64. Seely, Building the American Highway System, 55. 
Copyright of Annals of Iowa is the property of State of Iowa, by \& through the State Historical Society of Iowa and its content may not be copied or emailed to multiple sites or posted to a listserv without the copyright holder's express written permission. However, users may print, download, or email articles for individual use. 